International Journal of Life Sciences
Available online at http://sciencescholar.us/journal/index.php/ijls
Vol. 2 No. 3, December 2018, pages: $98 \sim 110$
e-ISSN: 2550-6986, p-ISSN: 2550-6994
https://doi.org/10.29332/ijls.v2n3.215

\title{
Fermented Rice Husk Utilization of Effective Microorganisms-4 Supplemented with Piper Betle L. Performance, Meat Quality, Antioxidant Capacity, and Meat Cholesterol Levels of Bali Duck
}

\author{
(C) CrossMark \\ Ida Bagus Gaga Partama a , Tjokorda Gede Belawa Yadnya ${ }^{\text {b }}$, Anak Agung Ayu Sri Trisnadewi c, \\ I Ketut Sukada d
}

Article history: Received 10 April 2018, Accepted: 30 August 2018, Published: 5 November 2018

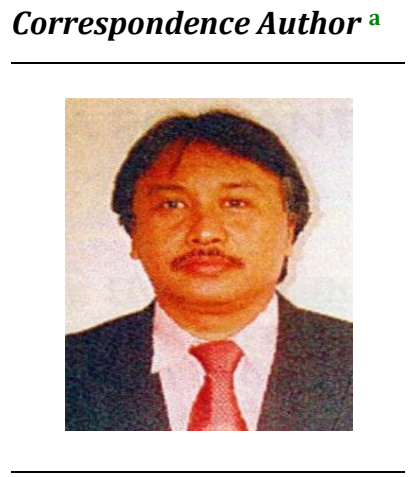

Keywords

Antioxidant capacity;

Bali duck;

Betle leaf meal;

Effective

Microorganisms-4;

Meat cholesterol

concentration;

\begin{abstract}
This experiment was conducted to study the effect of the offered effective microorganisms-4 fermented rice husk in diets and piper betle L. supplemented on performance, meat quality, antioxidant capacity, meat cholesterol levels of Bali duck. Research results showed that giving rations contain fermented rice husk and supplemented betle leaf (E treatment) on feed consumption was decreased significantly $(\mathrm{P}<0.05)$ with the treatment. Moreover, the offering treatmeat $\mathrm{C}, \mathrm{D}$ and $\mathrm{E}$ can increase of feed antioxidant consumption were significantly different $(\mathrm{P}<0.05)$, but with treatment $\mathrm{B}$ was decrase of feed antioxidant consumption $(\mathrm{P}<0.04)$ than the treatment $\mathrm{A}$. Therefore, the offering treatment $\mathrm{C}, \mathrm{D}$, and $\mathrm{E}$ can increased of feed digestibility, final body weight, and gain body weight were significntly different $(\mathrm{P}<0.05)$, but offering treatment $\mathrm{B}$ were not significantly of feed degestibility and final body weight $(P>0.05)$ and cotrasted with offering treatment $B$ can decreased of gain body weight, and on FCR was increased, but with treatment $C$, D can decrease FCR were significantly $(\mathrm{P}<0.05)$ than the treatment $\mathrm{A}$. The giving treatment $\mathrm{B}, \mathrm{C}, \mathrm{D}$, and $\mathrm{E}$ can increase of meat quality with organoleptic methods $(\mathrm{P}>0.05)$, but on meat quality with obyrcyive was not significantly different $(\mathrm{P}>0.05)$ than the treatment $\mathrm{A}$. The offering treatment $\mathrm{B}, \mathrm{C}, \mathrm{D}$, and $\mathrm{E}$ can be increased antioxidant capacity $(\mathrm{P}<0.05)$, but on cholesterol concentration with treatment $B$, and $C$ were not significantly different $(P>0.05)$, but treatment $\mathrm{D}$ and $\mathrm{E}$ can decrease of the cholesterol cooncentration $(\mathrm{P}<0.05)$ than the treatment $\mathrm{A}$., it could be concluded that giving treatment $\mathrm{E}$ gave the best response on performance, meat quality, antioxidant capacity, and meat cholesterol concentration of Bali ducks.
\end{abstract}

a Faculty of Animal Husbandry, Udayana University, Denpasar, Indonesia

b Faculty of Animal Husbandry, Udayana University, Denpasar, Indonesia

c Faculty of Animal Husbandry, Udayana University, Denpasar, Indonesia

d Faculty of Animal Husbandry, Udayana University, Denpasar, Indonesia 
e-ISSN: 2550-6986, p-ISSN: 2550-6994@ Copyright 2018. The Author.

SS Journals Published by Universidad Técnica de Manabí.

This is an open-access article under the CC BY-SA 4.0 license

(https://creativecommons.org/licenses/by-sa/4.0/)

All rights reserved.

\section{Contents}

Abstract

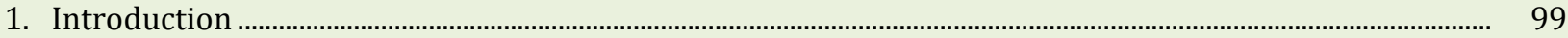

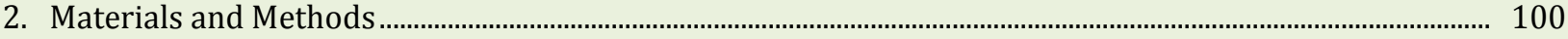

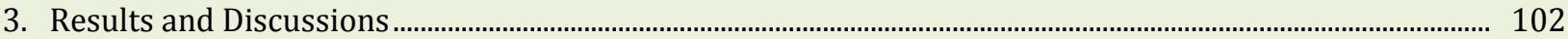

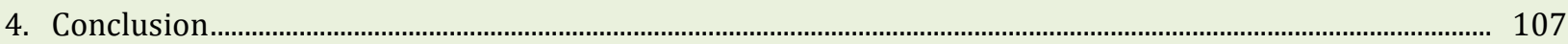

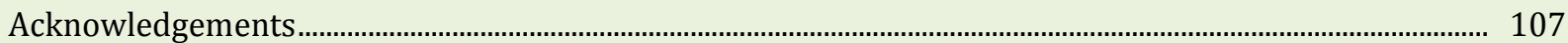

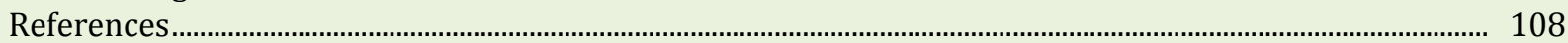

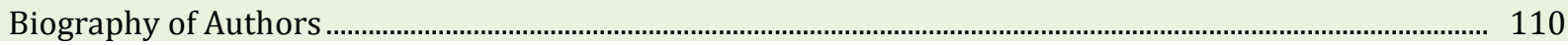

\section{Introduction}

The Bali duck (Anas Sp) is one of the local ducks Indonesian that had developed and maintained the Balinese and Lombok, have very high survival, and rarely pose high mortality figures. To characteristic than Bali duck has a plumage "sumi" is a favorite duck and including a duck laying productive type, followed by the Bali duck feathers "sumbian" feathers and crested honey buzzard. In addition also the livestock that can be as a source of animal protein in the form of meat and eggs (Murtidjo, 1988). But weakness in ducks that have aged or failed have cholesterol content trend relatively high enough and had a positive correlation against the content of cholesterol in meat and eggs (Setyawardani et al., 2001). To cope with the increased content of cholesterol can be done by making the ration formulation with the utilization of agricultural wastes or wastes of industrial agriculture, for example, the rice husk of required is quite high, due to the milling instead of rice grain retrieved $17 \%$ rice husk (Davendra, 1981).

Rice husk is a by-product of rice milling instead of the main results was the rice by-product (rice husk) produced quite abundant because rice is the staple food of Indonesian society. Rice husk as material feed alternatives has the content of nutrients is $12.5 \%$ water, $3.1 \%$ crude protein, $29.2 \%$ Ingredient Extracts Non Nitrogen (BETN), crude fiber 35\%, 2.7\% crude fat and $17.5 \%$ ash with a low digestibility (Lubis, 1992), and will effect against the efficiency of the use of ration. It is necessary, in order for his nutritional value of fermented fixable (Widyanto, 1995). One of the inoculants who used a high ration materials digest fiber rough is a solution of Effective Microorganisms-4 (EM-4) (Higa, 1993). Chandra et al., (2013) reported rice husk fermentation with a solution of effective microorganisms-4 (EM-4) can increase the nutritional content of rice husk that is crude protein from $1.92 \%$ to $2.67 \%$., crude fiber, from $37.33 \%$ to $13.02 \%$, Gross Energy (GE), from $302.33 \mathrm{kcal} / \mathrm{g}$ to $376,62 \mathrm{kcal} / \mathrm{g}$.

The granting of a ration of rice husk contains deaminated urea and supplementation by starbio (Roni et al., 2006); is the grant of 5.97\% rice husk and urea producing slaught weight lower than controls, but after treatment supplementation with starbio effect on carcass weight and slaught weight, while the percentage of carcass to happen increased significantly ( $\mathrm{P}<0.05)$. Granting dust wood deaminated urea and solution EM-4 does not have an effect on the appearance of the Bali duck is currently in a phase of growth (Yadnya et al., 2007). Yadnya et al., (2006) reported that the replacement of 50\% rice bran with rice husks or sawdust wood supplemented with starpig does not affect the efficiency of the use of ration but can improve the content of uric acid in the blood of a duck. To lower blood cholesterol levels can be done by supplemented with antioxidant compounds rations (Ishida et al., 2000), one of them with betle leaf (Piper betle L). Partama et al., (2018), reported that the betle leaf (Piper betle l.) have total phenolics and antioxidant activity is high enough that is $1070 \mathrm{mg} / 100 \mathrm{ml}$ and $97.44 \%$. Yadnya et al., (2014), reported the giving 5\% noni leaf, betle leaves, and purple sweet potato leaf can improve cholesterol levels, sugar levels and blood uric acid ducks. Susila et al.,

Partama, I. B., Yadnya, T. G., Trisnadewi, A. A. A. S., \& Sukada, I. K. (2018). Fermented rice husk utilization of effective microorganisms-4 supplemented with Piper betle L. performance, meat quality, antioxidant capacity, and meat cholesterol levels of Bali duck. International Journal of Life Sciences, 2(3), 98-110. https://doi.org/10.29332/ijls.v2n3.215 
(2015) the granting of Aspergillus niger fermented rice husk supplemented leaves the purple sweet potato (Ipomoea batatas l.) can improve the efficiency of the use of ration, carcass, profile antioxidant, cholesterol levels of meat ducks.

Based on the explanation on the background then used of the research study entitled "The study utilization of rice husk bio-fermented and supplemented betle leaf (Piper betle $L$ ) on performance, meat quality, capacity antioxidant, meat cholesterol concentration of Bali duck".

\section{Materials and Methods}

The study entitled study of the utilization of rice husk bio-fermented by bacteria lactobacillus complex (BLC) in supplemented flour rations betle leaf (Piper betle, $L$ ) against the antioxidant capacity, performance, carcass characteristic, meat quality, and cholesterol levels the female duck liver on the growth phase. The research was carried out in the village of duck appearances Guwang, Sukawati, Gianyar. for 12 weeks. The antioxidant capacity of the test carried out in Analytical Lab., Udayana University, for 4 weeks and cholesterol meat and liver in Rama's Clinic Lab., Denpasar, carcass in Livestock product technology Lab., Faculty of animal husbandry, Udayana University, for 4 weeks and the texture of the meat in a large Veterinary Lab., Pegok, Denpasar for 2 weeks.

\section{Ducks}

Ducks used in the study was ducks Bali, 12 weeks is obtained from I Made Sukariawan that came from Guwang Village, Sukawati district, Gianyar Regency, as many as 125 of the Bali ducktail with homogenous body weights.

\section{Cages and accessories}

In this study using the enclosure system battery two-story colony as much as 20 compartments. Each cage has a swath length $70 \mathrm{~cm}$, width $70 \mathrm{~cm}$, height $70 \mathrm{~cm}$. equipped with a Cage, food and a place to drink made of bamboo slats - that is located on the outside, and also comes with a container of dirt as well as holding the rest of the food, and are also equipped with lamps for lighting at night.

Ration ingredients, deamoniated urea, and biofermentation by bacteria lactobacillus complex (BLC) and flour betle leaf (Piper betle L.)

Ration ingredients used in this study was yellow corn, soybeans, copra meal, rice bran, rice husk, betel leaves, coconut oil, $\mathrm{NaCl}$, Urea, rice husk, lactobacillus bacteria complex. For the activity of microbial ineffective microorganisms-4 to make mashed with Effective Microorganisms-4 (EM-4) solution $100 \mathrm{ml}$, urea 100 gram and Molasses solution $100 \mathrm{ml}$ in the 10 liter of water in clenched then incubation for one day, further, rice husk is ready for fermented by solution it who had previously mixed with rice husk, and if it is lumped with the hand not apart put in a gunny sack vacuum and fermentation for a week. After being fermented then dried and ready to be utilized as an ingredient mixer rations (Yadnya et al., 2007). The betle leaf is obtained from the market of Desa Adat Peraman Guwang, Sukawati, Gianyar. Molasses and solution of EM-4 of shop Marketing Center products Oles Shop, Yangbatu, Denpasar.

\section{The composition of the ration for research}

Rations consisting of milled corn, soybeans, copra meal, rice bran, fish meal, B12, Minerals salts ( $\mathrm{NaCl}$ ), and rice husk. Rice husk is nothing without being processed and there are fermented with EM-4 solution, supplemented with leaves of Piper betle L. The composition the ration is found in Table 1 and containing nutrition of feed in Table 2. 
Table 1

Feed composition of ducks (12-24 weeks of age)

\begin{tabular}{lccccc}
\hline \multirow{2}{*}{ Ingredients (\%) } & \multicolumn{5}{c}{ Treatments } \\
\cline { 2 - 6 } Yellow corn & $\mathrm{A}$ & $\mathrm{B}$ & $\mathrm{C}$ & $\mathrm{D}$ & $\mathrm{E}$ \\
Soybean & 55.36 & 49.98 & 49.98 & 49.98 & 49.98 \\
Copra meal & 9.37 & 12.45 & 12.45 & 12.45 & 12.45 \\
Fish meal & 11.31 & 9.82 & 9.82 & 9.82 & 9.82 \\
Rice bran & 10.13 & 8.10 & 8.10 & 8.10 & 8.10 \\
Rice husk & 13.26 & 7.00 & 7.00 & 6.50 & 6.50 \\
Piper betle leaves & - & 12.50 & $12.50^{*}$ & 12.50 & $12.50^{*}$ \\
Coconut oil & - & - & - & 0.50 & 0.50 \\
Mineral B12 & - & 2.00 & 2.00 & 2.00 & 2.00 \\
NaCl & 0.50 & 0.50 & 0.50 & 0.50 & 0,50 \\
Total & 0.15 & 0.15 & 0.15 & 0.15 & 0.15 \\
& 100 & 100 & 100 & 100 & 100 \\
\hline
\end{tabular}

Table 2

The chemical composition of duck feed (12-24 weeks of age)

\begin{tabular}{lccccccc}
\hline \multirow{2}{*}{$\begin{array}{c}\text { Chemical } \\
\text { Composition }\end{array}$} & \multirow{2}{*}{ Unit } & \multicolumn{9}{c}{ Treatments } & Standard: Scott \\
\cline { 3 - 7 } & & $\mathrm{A}$ & $\mathrm{B}$ & $\mathrm{C}$ & $\mathrm{D}$ & $\mathrm{E}$ & et al., (1969). \\
\hline $\begin{array}{l}\text { Metabolizable } \\
\text { Energy }\end{array}$ & Kcal/kg & 2884.16 & 2859.08 & 2900.00 & 2858.32 & 2858.32 & $2800-2900$ \\
Crude Protein & $(\%)$ & 17.46 & 17.00 & 17.37 & 17.31 & 17.31 & $15-17$ \\
Ether Extract & $(\%)$ & 5.75 & 6.11 & 6.23 & 5.92 & 5.94 & $3-6$ \\
Serat Kasar & $(\%)$ & 4.63 & 8.23 & 7.34 & 8.84 & 7.24 & $6-9$ \\
Calsium (Ca) & $(\%)$ & 0.90 & 0.87 & 0.99 & 0.87 & 0.89 & 0.80 \\
$\begin{array}{l}\text { Phosphorus (P) } \\
\text { Avaible }\end{array}$ & $(\%)$ & 0.69 & 0.67 & 0.66 & 0.67 & 0.67 & 0.45 \\
\hline
\end{tabular}

Notes:

A : control diet (without rice hull and betle leaf meal); B : diet containing 12,5.0\% rice husk; C : diet containing $12,50 \%$ fermented ricehusk; D : diet containing $12,50 \%$ rice husk and $0.50 \%$ betle leaf meal;

$\mathrm{E}$ : diet containing $12,50 \%$ rice husk and $0.50 \%$ betle leaf meal

\section{Research Design}

Research design used was Complete Random Design (CRD) with five treatments, namely control ration, ration without rice husk (A); rations with $12.50 \%$ rice husk fermentation without (B); rations with $12.50 \%$ fermented rice husk and betle leaf (C); rations with $12.50 \%$ rice husk without fermented and betle leaf (D); rations with $12.50 \%$ fermented rice husk and betle leaf (E). Each of the treatments with four replicates each and Deuteronomy contains five Bali duck-tailed females the initial body with weights and age homogeneity.

The observed variable

The observed variables include the appearance (the consumption of rations, antioxidant consumption of rations, the final body weights, body weight and added the Feed Conversion Ratio), characteristic of the

Partama, I. B., Yadnya, T. G., Trisnadewi, A. A. A. S., \& Sukada, I. K. (2018). Fermented rice husk utilization of effective microorganisms-4 supplemented with Piper betle L. performance, meat quality, antioxidant capacity, and meat cholesterol levels of Bali duck. International Journal of Life Sciences, 2(3), 98-110. https://doi.org/10.29332/ijls.v2n3.215 
carcass (carcass weight, cut Weight, carcass composition, carcass percentage), the meat quality consisted of organoleptic methods, objective methods, and meat texture, antioxidant profile consisted of antioxidant capacity, malondialdehyde, superoxide dismutase, lipid profile of meat consisted of cholesterol total, triglycerides, HDL and LDL

\section{Data Analysis}

The data obtained were analyzed with prints and when there is a noticeable difference between the treatment continued with test Duncan (Steel and Torrie, 1989).

\section{Results and Discussions}

Study of the influence of offering ration rice husk deaminated Urea and bio-fermented that supplemented betle leaf on the performance of the Bali Duck.

Consumption of Rations

Consumption of rations on the ducks get a ration of rice husk and without betle leaf or treatment (control) for 12 weeks is 5.786.25 grams/duck (Table 3). The ducks get $12.50 \%$ rice husk without fermentation (treatment B) an increase in the consumption of rations significantly $(\mathrm{P}<0.05)$. The grant of a ration containing fermented rice husk $12.50 \%$ (treatment $\mathrm{C}$ ), $12.50 \%$ rice husk without fermentation and betle leaves (treatment D), and $12.50 \%$ rice husk fermented and betle leaves (treatment E) different rations consumption decline markedly $(\mathrm{P}>0.05)$ compared to treatment A. Increased consumption of rations caused by rice husk that cause low digestion, so the treatment B consumes more rations in order to fulfill their needs (Anggorodi, 1984). The results obtained in accordance with the digestion study by Yadnya et al., (2015), rations, containing betle leaves as antioxidants can increase the metabolic processes are included in the process of digestion can be increased, so that the need for energy and substances other nutrients could be fulfilled.

Table 3

Study of the influence of offered ration rice husk deaminated urea and bio-fermented supplemented betle leaf on the performance of the Bali duck

\begin{tabular}{|c|c|c|c|c|c|c|}
\hline \multirow{2}{*}{ Variable } & \multicolumn{5}{|c|}{ Treatments } & \multirow{2}{*}{ SEM } \\
\hline & A & B & $\mathrm{C}$ & $\mathrm{D}$ & $E$ & \\
\hline $\begin{array}{l}\text { Feed consumption } \\
\text { (gr/duck) }^{\text {NS }}\end{array}$ & $5.786,25 \mathrm{c}$ & $6.143,75 a$ & $5774,75 \mathrm{~cd}$ & $5845,25 b$ & $5745,25 d$ & 11,44 \\
\hline $\begin{array}{l}\text { Feed Anttioxidant } \\
\text { Capacity (\%IC) }\end{array}$ & $3,47 c$ & $3,26 \mathrm{cb}$ & $4,96 b$ & $5,10 \mathrm{a}$ & $5,25 a$ & 0,093 \\
\hline $\begin{array}{l}\text { Final Body Weight } \\
\text { (Kg/duck) }\end{array}$ & $1.368 \mathrm{~b}$ & $1.335 b$ & $1.496 \mathrm{a}$ & $1.505 a$ & $1.595 \mathrm{a}$ & 0.041 \\
\hline $\begin{array}{l}\text { Body weight gain } \\
\text { (g/duck) }\end{array}$ & $417.75 c$ & $384,00 d$ & $545,00 \mathrm{~b}$ & $553,00 \mathrm{~b}$ & $644,25 a$ & 8,536 \\
\hline Feed Conversion Ratio) & $13.71 b$ & $16.00 \mathrm{a}$ & $10,59 \mathrm{c}$ & $10,55 c$ & $8,91 \mathrm{~d}$ & 0,186 \\
\hline
\end{tabular}

Notes: A : control diet (without rice hull and betle leaf meal); B : diet containing 12,5.0\% rice husk; $\mathrm{C}$ : diet containing 12,50\% fermented rice-husk; D : diet containing 12,50\% rice husk and $0.50 \%$ betle leaf meal; E : diet containing $12,50 \%$ rice husk and $0.50 \%$ betle leaf meal

NS: Non-Significant $\mathrm{P}>0,05$ )

SEM: Standard error the treatment means 


\section{Feed Antioxidant Capacity}

Feed antioxidant capacity in the ducks who get treatment $\mathrm{A}$ is 3,47\% IC (Table 3). Administering treatment $B$ can reduce the antioxidant capacity of $6.05 \%$ was not significantly different $(\mathrm{P}>0.05)$ while with the treatments C, D and E may improve antioxidant capacity each ration $42.93 \%, 46.97 \%$ and $51.25 \%(\mathrm{P}<0.05)$ compared to treatment $A$. The presence of antioxidant capacity can improve fermentation. The results of this research as conducted by Susila et al., (2016) that get an increase in antioxidant capacity of the ration of fermented rice husk and supplemented purple sweet potato leaf. According to Yadnya et al., (2016), granting of fermented rice husk, with a solution of EM 4-supplemented MSG can increase the antioxidant capacity of rations

\section{The final body weights}

The final body weights on the duck were 1368.00 gram/duck (Table 3). The giving of treatment B generates the final body weight lower $(\mathrm{P}>0.05>)$, thus giving treatments $\mathrm{C}, \mathrm{D}$ and $\mathrm{E}$ can increase final body weight the end respectively amounted to $9.35,10.01$., and 16.59\% (P 0.05) than granting < treatment A. Increased body weight the end very affected by the quality of the nutrition value of rations as well as the value of the digestion ration increases so that the nutrient substances can be absorbed more and more so living ducks can be fulfilled (Yadnya and Trisnadewi, 2012). The results of this study in accordance with obtained by Susila et al., (2016), that fermented supplemented ration granting leaves of sweet potato purple can body weights produces the end better than other treatments.

\section{Body Weights Gain}

Body weight gain on duck was 417, 75gram/tail (table 3) the giving of treatment B can lower the value of different body weights real $(\mathrm{P}<0.05)$, whereas treatment with the administration of treatment $\mathrm{C}, \mathrm{D}$ and $\mathrm{E}$ can increase body weight increase each of 30.46., 32.37., 54.21\% were significantly different $(P<0.05)$ compared to treatment A. The presence of enzymes contained in solution EM-4 Widiana and Higa (1993) and antioxidant compounds in a betle leaf (Piper betle L.) so that the digestibility rations can be increased the body weight gain occurred. Susila et al., (2016), reported that giving ration fermented rice husk and supplemented of sweet potato purple (Ipomoea batatas l.) leaves can produce a body weight added better than ducks fed a control treatment.

\section{Feed Conversion Ratio (FCR)}

Feed conversion ratio (FCR) of Bali duck in treatment A was 13,71 (Table 3). Presented treatment B can increase FCR amount 16.70 percentage was not significantly than those in the control diet Moreover, FCR of ducks in treatment $\mathrm{C}, \mathrm{D}$ and $\mathrm{E}$ can decrease were significantly different $(\mathrm{P}<0,05)$ than that treatment $\mathrm{A}$. FCR very depend on feed consumption and body weight gain (Yadnya et al., 2013). Feed consumption the affected containing nutrition value, because on treatment B content $12.50 \%$ rice husk as source crude fibre very difficult for digest by bird that have not digestion for crude fibre and have low digest that low small material can that for absorption nutrition very low, so that decrease for body weight gain (Anggrogodi, 2005). According to Susila et al., (2015), Offered ration containing fermented rice husk with Aspergillus niger and supplemented Ipomoea batatas L leaf can improve the performance of Bali duck included body weight and FCR.

Study of the influence of offering ration rice husk deaminated Urea and bio-fermented that supplemented betle leaf on meat quality of the Bali duck meat quality with organoleptic methods variable organoleptic meat quality was color, smell, texture, taste, and to receive of the whole. Score color meat duck A was 3.20. (Table 4). Offered treatment $B, C, D$, and $E$ can increase score color were significantly different $(P<0,05)$ than to treatment A.The increasing of the color of meat very the affect by protein consumption and antioxidant consumption. This result of the research was suitable with the experiment of Yadnya et al., (2015), reported

Partama, I. B., Yadnya, T. G., Trisnadewi, A. A. A. S., \& Sukada, I. K. (2018). Fermented rice husk utilization of

effective microorganisms-4 supplemented with Piper betle L. performance, meat quality, antioxidant capacity, and meat cholesterol levels of Bali duck. International Journal of Life Sciences, 2(3), 98-110. https://doi.org/10.29332/ijls.v2n3.215 
that offered ratio containing fermented Aspergillus niger and supplemented purple sweet potato (Ipomoea batatas $L$ ) leaf can increase color score with organoleptic methods.

Table 4

Study of the influence of offering fermented rice husk with effective microorganisms-4 (EM-4 in diets supplemented betle leaf on meat quality of the Bali duck with organoleptic methods

\begin{tabular}{lcccccc}
\hline \multirow{2}{*}{ Variable } & \multicolumn{5}{c}{ Treatment } & \multirow{2}{*}{ SEM } \\
\cline { 2 - 6 } & $\mathrm{A}$ & $\mathrm{B}$ & $\mathrm{C}$ & $\mathrm{D}$ & $\mathrm{E}$ & \\
\hline Color & $3.20 \mathrm{~d}$ & $3.40 \mathrm{c}$ & $3.46 \mathrm{~b}$ & $3.80 \mathrm{~b}$ & $3.89 \mathrm{a}$ & 0.049 \\
Smell & $3.20 \mathrm{~d}$ & $3.60 \mathrm{c}$ & $3.93 \mathrm{~b}$ & $3.88 \mathrm{~b}$ & $4.23 \mathrm{a}$ & 0.046 \\
Texture & $3.20 \mathrm{~d}$ & 3.63 & $3.82 \mathrm{~b}$ & $3.85 \mathrm{~b}$ & 3.95 & 0.048 \\
Taste & $3.40 \mathrm{c}$ & $3.60 \mathrm{c}$ & $3.80 \mathrm{~b}$ & $4.23 \mathrm{a}$ & $4.40 \mathrm{a}$ & 0.083 \\
To recive of whole & $3.4 \mathrm{~d}$ & $3.60 \mathrm{~d}$ & $3.80 \mathrm{c}$ & $4.10 \mathrm{~b}$ & $4.40 \mathrm{a}$ & 0.073 \\
\hline
\end{tabular}

Notes: A : control diet (without rice hull and betle leaf meal); B : diet containing 12,5.0\% rice husk; C : diet containing $12,50 \%$ fermented rice-husk; $\mathrm{D}$ : diet containing $12,50 \%$ rice husk and $0.50 \%$ betle leaf meal; $\mathrm{E}$ : diet containing $12,50 \%$ fermented rice husk and $0.50 \%$ betle leaf meal

NS: Non-Significant $(\mathrm{P}>0,05)$

SEM: Standard Error The Treatment Means

Score smell meat to duck offering ration containing without rice husk in diet was 3.20 (Table 4), thus giving treatment B, C, D, and E could increase of score smell of meat respectively were 12.50., 22.81., 21.25, and $32.18 \%$ were significantly different $(\mathrm{P}<0.05)$ than treatment $\mathrm{A}$. Decreased smell and rancid meat ducks get piper betle $L$ as in the beetle leaf in diets contains compound which is antioxidant that can prevent oxidation by free radicals (Hustani, 2001). Rumiasih et al., (2011) reported that the supply of rations containing antioxidants can reduce odor off on the meat duck. Scoring value with the organoleptic taste of duck meat, show that offered treatment $\mathrm{E}$ is the most preferred treatments. This is due to shrinkage of meat cooking on the lowest among ducks treatment, so the nonprotein substance that dissolves in water and fat as the precursors of meat flavor that is greater than the other treatment (Soeparno, 2005).

Winarno (1986) reported that the flavor determined by smell, taste, and savor with the presence of antioxidants in the diet that contained in the unfermented or fermented rice husk could reduce oxidation by radicals. In the case, less saturated fatty acids oxidized could reduce off-odor intensity.

The score of duck meat texture in treatment A was 3.20 (see in table 4). Offered treatment B, C, D, and E can increased meat texture score respectively were 12.50 ., 22.81 ., 20.31 ., and $23.43 \%$ significantly different $(\mathrm{P}<0.05)$ compared than treatment A. Susila et al., (2016) reported that offered fermented or without fermented on rice husk can improve texture meat with organoleptic method. Tenderness of meat is determined by 3 components, such as myofibrils and its status of contraction, the connective tissue content of cross linking, water holding capacity (WHC) of protein in meat juice (Soeparno, 2005). Susila et al., (2016) reported that offered fermented rice husk that supplemented purple sweet potato could improve meat texture, included colour, smell, taste, and texture compare duck offered diet without fermented rice husk.

Score taste meat to duck offering ration containing without rice husk in diet was 3.20 (Table 4), thus giving treatment B, C, D, and E could increase of score smell of meat respectively were 5.88., 17.64., 24.41, and $29.41 \%$ were significantly different $(\mathrm{P}<0.05)$ than treatment A. Score taste meat very determine by smell, feeling, to taste, with there is antioxidant in beetle leaf can reduce oxidation unsaturated by free radical and intensity off-odor can reduce (Borovička \& Řanda (2007).

The Study showed that total acceptance with treatment A for meat A was 3.40 (Table 4). In the treatment B, C, D, and E can increased score total acceptance respectively 5.88., 11.76., 20.58., and 29.41\% were significantly different $(\mathrm{P}<0.05)$ compared with treatment A. Susila et al., (2016) reported that offered fermented rice husk as diet antioxidant could improve color, smell, taste, texture, and total acceptance. The total acceptance is a combination from some variables organoleptic test on meat product, so existence of abetter meat variable. 
Study of the influence of offering fermented rice husk with effective microorganisms-4 (EM-4 in diets supplemented betle leaf on meat quality of the Bali Duck with organoleptic methods

Water meat concentration to duck provision treatment A was 74.75\% (Tabel 4). Provision treatment B, C, $D$, and E production water meat concentration were not significantly $(p>0,05)$ compared than treatment $A$. Water meat concentration the affected by water consumption and water metabolism through metabolism of protein, lipid, and carbohydrate water until formation balance condition (Murray et al., 2009). The resulting research is nearly same with pound Yadnya et al., (2016), reported that offered ration containing fermented rice husk with effective microorganisms-4 (EM-4) supplemented Mono Sodium Glutamate (MSG) get water meat concentration not significantly different $(\mathrm{P}>0.05)$ with control treatment. Yadnya et al., (2015) reported that offered ration containing fermented purple sweet potato skin product water meat concentration nearly same with offered treatment control.

It showed that in Table 5. Offered treatment $\mathrm{B}, \mathrm{C}, \mathrm{D}$, and $\mathrm{E}$ were not significantly $(\mathrm{P}>0.05)$ of $\mathrm{pH}$, water holding capacity (WHC), and cooking loss (CL). compared than.

Table 5

Study of the influence of offering fermented rice husk with betle leaf supplemented of meat duck quality with objective methods

\begin{tabular}{lcccccc}
\hline & \multicolumn{5}{c}{ Perlakuan } & SEM \\
\cline { 2 - 6 } Variable & $\mathrm{A}$ & $\mathrm{B}$ & $\mathrm{C}$ & $\mathrm{D}$ & $\mathrm{E}$ & SEM \\
\hline Water Concentration (\%) & 74,75 & 74,53 & 73,24 & 75,19 & 75,42 & 4,744 \\
pH $^{\mathrm{NS}}$ & 5,57 & 5,54 & 5,69 & 5,66 & 5,71 & 0,11 \\
$\quad$ Holding Capacity (WHC) & 38,36 & 44,24 & 35,32 & 37,44 & 35,72 & 35,52 \\
Ns(\%) & & & & & & \\
Cooking Loss (CL) & & & & \\
& 32,85 & 31,81 & 31,65 & 31,14 & 30,70 & 3,004 \\
\hline
\end{tabular}

Notes: A : control diet (without rice hull and betle leaf meal); B : diet containing 12,5.0\% rice husk; C : diet containing $12,50 \%$ fermented rice-husk; D : diet containing $12,50 \%$ rice husk and $0.50 \%$ betle leaf meal; $\mathrm{E}$ : diet containing $12,50 \%$ fermented rice husk and $0.50 \%$ betle leaf meal

NS: Non-Significant $(\mathrm{P}>0,05)$

SEM: Standard Error The Treatment Means.

Treatment A. From result research to get water concentration, $\mathrm{pH}$, and protein concentration of the meat were not significantly different $(\mathrm{P}>0.05)$ can the affected of another compound. WHC effected meat containing protein and pH (Soeparno, 2005). The increase of WHC could apply water to meat which causes an increase in protein, so it could also of WHC value. Lawrie (1995) reported that high cooking loss could produce more nutrients lost during the process WHC. Meat has its capability to bring water molecule, depend on the amount of protein when there was a decreased activity (Purnomo et al., 1989). A cooking loss could be measured when there was a decrease in WHC value. Lawrie (1995) reported that high cooking loss could produce more nutrients lost during the process of boiling.

Study of the influence of offering fermented rice husk with betle leaf supplemented of meat antioxidant capacity, meat and liver cholesterol levels of Bali duck

Meat Antioxidant Capacity

Meat antioxidant capacity on duck offering treatment A was 9.56I\% (Table 7). Offering treatment B, C, D, and E can increased meat antioxidant capacity respectively 52.61., 85.98., 89.12, and $121.23 \%$ were significantly different $(\mathrm{P}<0.05)$ compared to treatment $\mathrm{A}$. If antioxidant consumption higher shall to effected contain antioxidant in higher meat. Yadnya et al., (2015) reported that to getting ration fermented rice husk

Partama, I. B., Yadnya, T. G., Trisnadewi, A. A. A. S., \& Sukada, I. K. (2018). Fermented rice husk utilization of effective microorganisms-4 supplemented with Piper betle L. performance, meat quality, antioxidant capacity, and meat cholesterol levels of Bali duck. International Journal of Life Sciences, 2(3), 98-110. https://doi.org/10.29332/ijls.v2n3.215 
and betle leaf supplemented can increase antioxidant capacity in the blood and meat of Bali duck. Prangdimurti et al., (2006) reported that offering suji leaf on a rat, and can be increased of blood antioxidant capacity compared to rat fed without leaf.

Table 7

Study of the influence of offering fermented rice husk with betle leaf supplemented of meat antioxidant, meat and liver cholesterol levels of Bali duck

\begin{tabular}{ccccccc}
\hline \multirow{2}{*}{ Variabel } & \multicolumn{5}{c}{ Treatments } & \multirow{2}{*}{ SEM } \\
\cline { 2 - 6 } & $\mathrm{A}$ & $\mathrm{B}$ & $\mathrm{C}$ & $\mathrm{D}$ & $\mathrm{E}$ & \\
\hline Antioxidant capacity(IC\%) & $9,56 \mathrm{c}$ & $14,59 \mathrm{~b}$ & $17,78 \mathrm{~b}$ & $18,08 \mathrm{~b}$ & $21,15 \mathrm{a}$ & 1,393 \\
Meat Cholesterol (mg/dg) & $219.59 \mathrm{a}$ & $185.29 \mathrm{a}$ & $173.58 \mathrm{a}$ & $156.71 \mathrm{~b}$ & $144.23 \mathrm{~b}$ & 16.48 \\
\hline
\end{tabular}

Notes: A : control diet (without rice hull and betle leaf meal); $\mathrm{B}$ : diet containing 12,5.0\% rice husk; C : diet containing 12,50\% fermented rice-husk; D : diet containing $12,50 \%$ rice husk and $0.50 \%$ betle leaf meal; E : diet containing 12,50\% fermented rice husk and $0.50 \%$ betle leaf meal.

NS: Non-Significant $(\mathrm{P}>0,05)$.

SEM: Standard Error The Treatment Means

\section{Meat Cholesterol Concentration}

Meat cholesterol on duck offering treatment A was $219,59 \mathrm{mg} / \mathrm{dg}$ (Table 7). Provision treatment B and C produce meat cholesterol were not significantly different $(\mathrm{P}>0.05)$, but with offering treatment $\mathrm{D}$ and $\mathrm{E}$ can decreased of meat cholesterol, respectively $28.63 \%$ and $34.31 \%$ were significantly different $(\mathrm{P}<0.05)$ compared to treatment A, Moreover, on liver also in case, to giving treatment B was not significant of cholesterol $(\mathrm{P}>0.05)$ but offering treatment $\mathrm{C}, \mathrm{D}$, and $\mathrm{E}$ can decrease liver cholesterol were significantly $(\mathrm{P}<0.05)$ compared to treatment $\mathrm{A}$. 


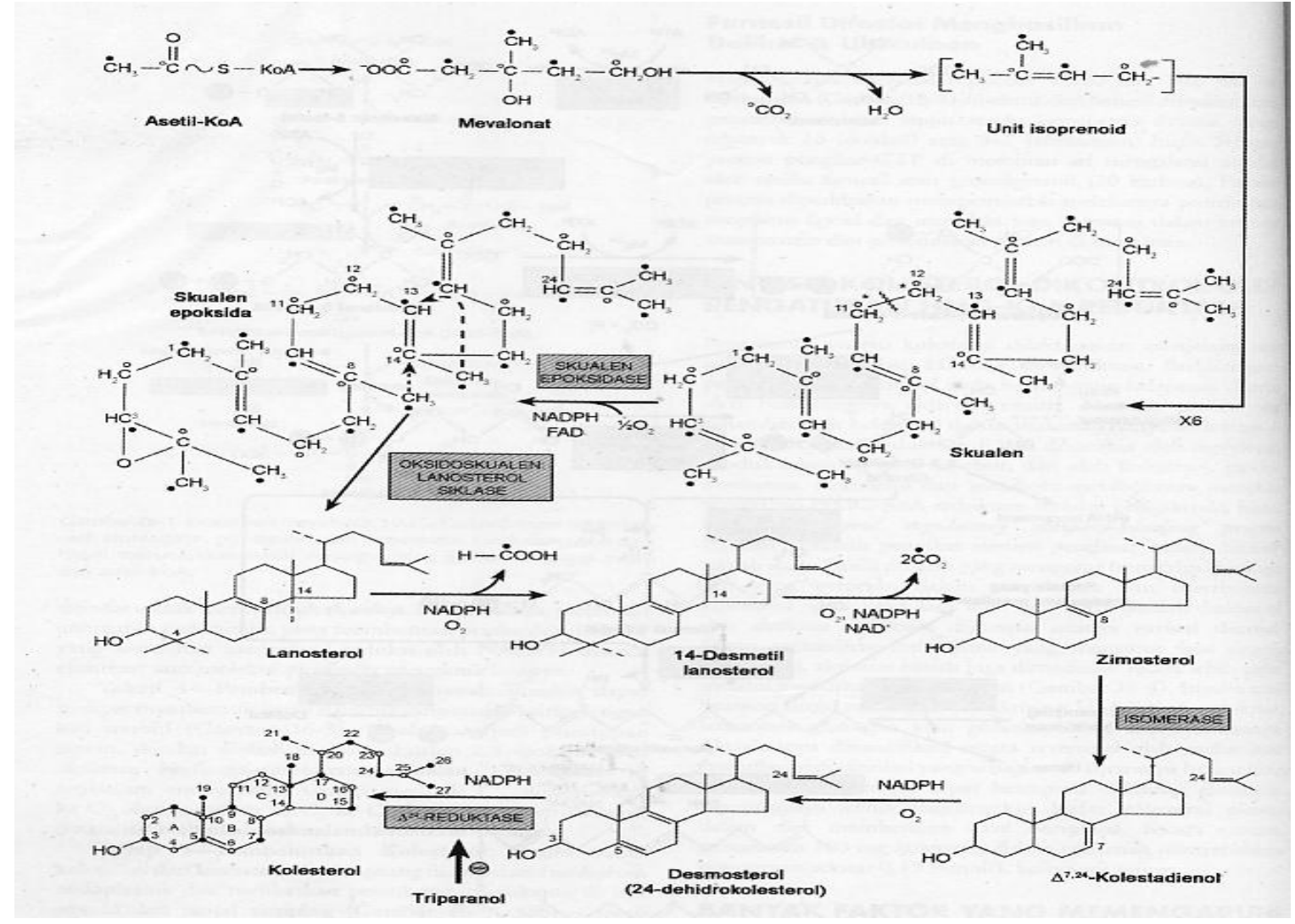

\section{Conclusion}

It was concluded that offering ration containing fermented rice husk and betle leaf supplemented can improve performance, meat quality, antioxidant capacity, and meat cholesterol of Bali duck.

\section{Acknowledgments}

The author would like to thank Directorate General of Empowerment Research and Development, The Ministry of Technology Research and Higher Education the Republic of in February onesie for the fund through Rector and Institute for Research and Community Service Udayana University Contract Agreement Number: 171.122//UN.14.4.A/LT//2018, in February 19th, 2018.

Partama, I. B., Yadnya, T. G., Trisnadewi, A. A. A. S., \& Sukada, I. K. (2018). Fermented rice husk utilization of effective microorganisms-4 supplemented with Piper betle L. performance, meat quality, antioxidant capacity, and meat cholesterol levels of Bali duck. International Journal of Life Sciences, 2(3), 98-110. 


\section{References}

Anggorodi, R. (1979). Ilmu makanan ternak umum. Gramedia.

Borovička, J., \& Ǩanda, Z. (2007). Distribution of iron, cobalt, zinc and selenium in macrofungi. Mycological Progress, 6(4), 249.

Chandra, A., Copen, C. E., \& Mosher, W. D. (2013). Sexual behavior, sexual attraction, and sexual identity in the United States: Data from the 2006-2010 National Survey of Family Growth. In International handbook on the demography of sexuality (pp. 45-66). Springer, Dordrecht.

Davendra, C. (1981). Socio-Economic Importance of Goat Population. Gall. C.(ed.), Goat Production, Academic Press, London.

Higa, I., \& Fuyama, Y. (1993). Genetics of food preference inDrosophila sechellia. Genetica, 88(2-3), 129-136.

Hustani, M. N. (2009). Uji Aktivitas Antibakteri Ekstrak Etanol Daun Salam (Syzygium polyanthum Wight) terhadap Bakteri Penyebab Diare. Skripsi. Fakultas Ilmu Kedokteran dan Ilmu Kesehatan Universitas Jenderal Soedirman.

Ishida, H., Campbell, S., \& Blackwell, J. (2000). General approach to nanocomposite preparation. Chemistry of Materials, 12(5), 1260-1267.

Lawrie, S. M., \& Abukmeil, S. S. (1998). Brain abnormality in schizophrenia: a systematic and quantitative review of volumetric magnetic resonance imaging studies. The British Journal of Psychiatry, 172(2), 110120.

Lubis, D. A. (1992). Ilmu makanan ternak umum. Penerbit PT. Pembangunan. Jakarta.

Murray, L. J., Dincă, M., \& Long, J. R. (2009). Hydrogen storage in metal-organic frameworks. Chemical Society Reviews, 38(5), 1294-1314.

Murtidjo, B. A. (1988). Mengelola Ternak Itik. Penerbit Kanisius, Yogyakarta.

Partama, I. B. G., Yadnya, T. G. B., Trisnadewi, A. A. A. S., \& Sukada, I. K. (2018). Increasing nutrition value of fermented rice hull through biofermentation of lactobacillus complex bacteria supplemented. International Journal of Life Sciences, 2(2), 73-82.

Prangdimurti, E., Muchtadi, D., Astawan, M., \& Zakaria, F.

Purnomo, A. S., Kamei, I., \& Kondo, R. (2008). Degradation of 1, 1, 1-trichloro-2, 2-bis (4-chlorophenyl) ethane (DDT) by brown-rot fungi. Journal of bioscience and bioengineering, 105(6), 614-621.

Roni, N. G. K., Sukmawati, N. M., \& Sriyani, N. L. P. (2006). Pengaruh Pemberian Ransum Mengandung Sekam Padi Diamoniasi disuplementasi dengan Zat Probiotik terhadap Bobot Badan, Perlemakan Tubuh, dan Karkas Ayam Broiler. Laporan Penelitian, Fakultas Peternakan, Universitas Udayana.

RUMIASIH, R. (2011). Penerapan Strategi Pembelajaran Guided Note Taking Dengan Media Torso Untuk Meningkatkan Hasil Belajar Biologi Siswa Kelas Viii F Smp Negeri 3 Kartasura Tahun Pelajaran 2010/2011 (Doctoral dissertation, Universitas Muhammadiyah Surakarta).

Scott, M. L., Nesheim, M. C., \& Young, R. J. (1969). Nutrition of the chicken. Nutrition of the chicken.

Setyawardani, T. D., \& Ningsih, D. F. (2001). Acarwah. 2001. pengaruh Pemberian Ekstrak Buah Nanas dan Pepaya terhadap Kualitas Daging Itik Petelur Afkir. Buletin Peternakan, diterbitkan oleh Fakultas Peternakan, Universitas Gadjah mada, Yogyakarat, Indonesia. ISSN-02126-440. Edisi Tambahan.

Steel, K. P., \& Barkway, C. H. R. I. S. (1989). Another role for melanocytes: their importance for normal stria vascularis development in the mammalian inner ear. Development, 107(3), 453-463.

Suparno, P. (2005). Miskonsepsi \& perubahan konsep pendidikan fisika. Jakarta: PT. Grasindo.

Susila, W. R. (2004). Contribution of oil palm industry to economic growth and poverty alleviation in Indonesia. Jurnal Litbang Pertanian, 23(3), 107-114.

Widdiana, G. N., \& Higa, T. (1995, June). Effect of EM on the production of vegetable crops in Indonesia. In 4th Proc. Int. Conf. Kysei Nature Farmingheld in Paris, France (pp. 79-84).

Widyanto, S. A. (2007). Pengembangan Teknologi Rapid Prototyping untuk Pembuatan Produk-Produk Multi Material. ROTASI, 9(4), 10-14.

Winarno, F. G. (1986). Production and uses of soybean tempe. Food Uses of Whole Oil and Protein Seeds, 102130.

Yadnya, T. B., Trisnadewi, A. A. A. S., Sukada, I. K., \& Oka, I. G. L. (2016). The Effect of Fermented Purple Sweet Potato (Ipomoea batatas L) Skin in Diets on Feed and Anthocyanin Consumption, Carcass Characteristics, Anthioxidant Profile and Meat Texture of Bali Duck. Journal of College and University. This is an open access article under the, 2454, 2261. 
Yadnya, T. G. B., \& Trisnadewi, A. A. A. S. (2011). Improving the Nutrition of Purple Sweet Potato (Ipomoea batatas L) through Biofermentation of Aspergillus niger as Feed Substance Containing Antioxidants.

Yadnya, T. G. B., Partama, I. B. G., \& Sri, A. A. A. response of offered fermented purple sweet potato (Ipomoea batatas L) skin as antioxidant compound in diets improved meat quality of bali duck.

Yadnya, T. G. B., Partama, I. B. G., \& Trisnadewi, A. A. A. S. (2012). Pengaruh pemberian ransum yang mengandung ubi jalar ungu (Ipomoea batatas L) terfermentasi Aspergillus niger terhadap kecernaan ransum, retensi protein, dan pertambahan bobot badan itik bali. Prosiding Semnas FAI.

Yadnya, T. G. B., Partama, I. B. G., \& Trisnadewi, A. A. A. S. (2012). Pengaruh pemberian ransum yang mengandung ubi jalar ungu (Ipomoea batatas L) terfermentasi Aspergillus niger terhadap kecernaan ransum, retensi protein, dan pertambahan bobot badan itik bali. Prosiding Semnas FAI.

Yadnya, T. G. B., Sukmawati, N. M. S., \& Budiasa, I. K. M. (2007, July). Pengaruh pemberian serbuk gergaji kayu yang diamoniasi terfermentasi dan daun salam dalam ransum terhadap penampilan, karkas dan kadar kolesterol darah itik bali. In Prosiding Seminar Nasional, Fakultas Peternakan, UGM, Yogyakarta (pp. 2427).

Yadnya, T. G. B., Sukmawati, N. M. S., \& Wirawan, I. W. (2013, October). Pemanfaatan daun ubi jalar ungu dalam ransum disuplementasi Starpig terhadap kadar kolesterol serum darah dan karkas itik bali. In Makalah Seminar Nasional. Fakultas Agroindustri, Universitas Mercu Buana, Yogyakarta (Vol. 9).

Yadnya, T. G. B., Trisnadewi, A. A. A. S., Aryani, I. G. A. I., \& Oka, I. G. L. (2014). noni (Morinda ctrifolia L), and Beetle (Piper betle L) in diets improved blood chemical profile of bali duck. J. Biol. Chem. Research, 31(1), 538-545.

Yadnya, T. G. B., Wirawan, I., Wibawa, A. A. P. P., \& Sukmawati, D. (2017). Upaya Perbaikan Nutrisi Dan Profil Lipidatelur Pada Itik Bali Yang Mendapatkan Sekam Padi Mengandung Daun Noni (Morinda citrifolia L) Disuplementasi Multienzim. Majalah Ilmiah Peternakan, 20(2), 49-54.

Yadnya, T., Trisnadewi, A., Sukada, I., \& Oka, I. (2016). The Effect of Offered Diet Containing Rice Hull and Mono Sodium Glutamte (Msg) And Effective Microorganism -4 (Em-4) Solution on The Performance of Campbell Duck. International Research Journal Of Engineering, IT \& Scientific Research, 2(11), 66 - 72.

Partama, I. B., Yadnya, T. G., Trisnadewi, A. A. A. S., \& Sukada, I. K. (2018). Fermented rice husk utilization of effective microorganisms-4 supplemented with Piper betle L. performance, meat quality, antioxidant capacity, and meat cholesterol levels of Bali duck. International Journal of Life Sciences, 2(3), 98-110. https://doi.org/10.29332/ijls.v2n3.215 


\section{Biography of Authors}

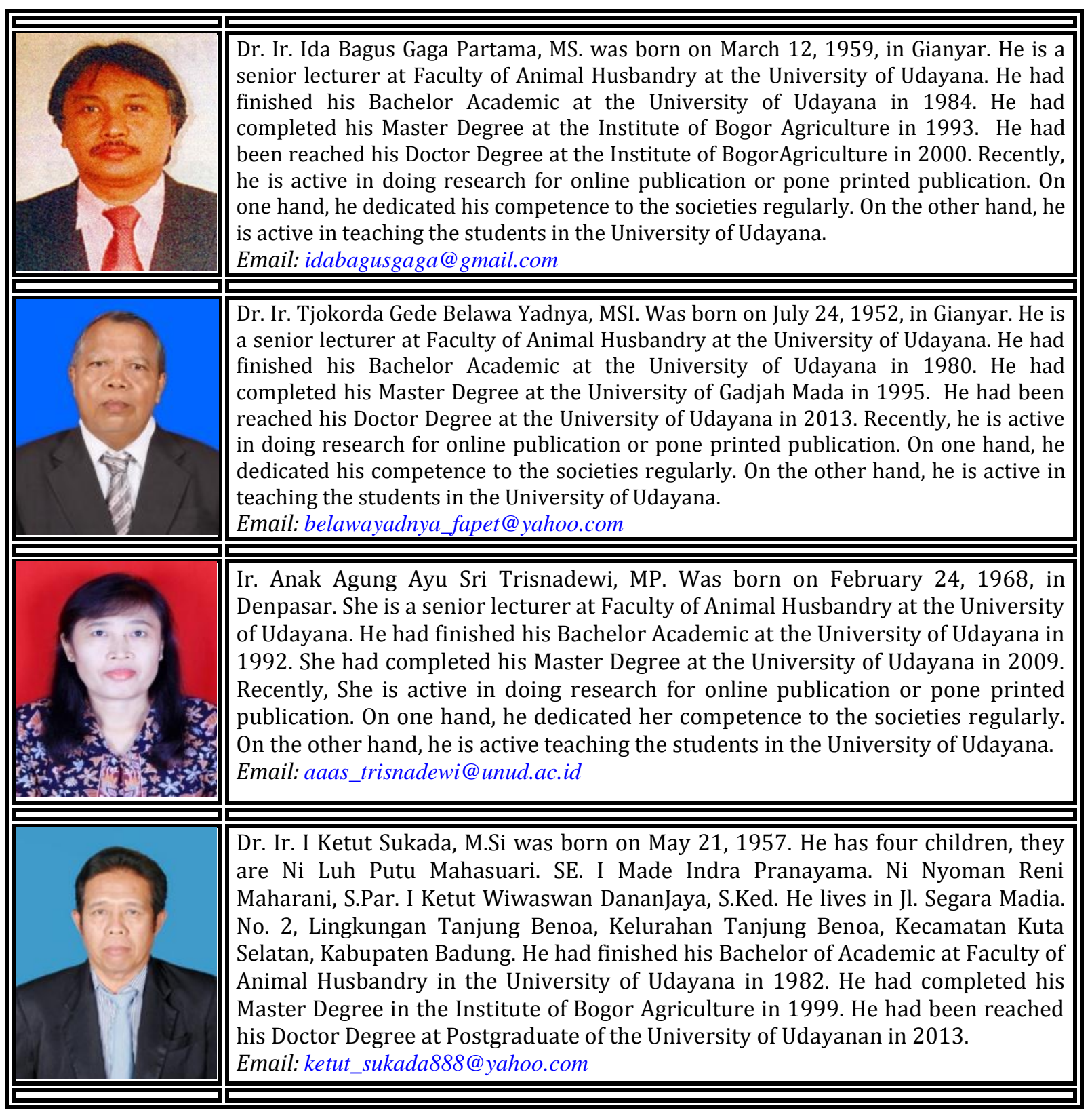

